\title{
NÉMETH Miklós
}

Szegedi Tudományegyetem

Bölcsészet- és Társadalomtudományi Kar

Szeged, Magyarország

nicola@hung.u-szeged.hu

\section{GENERÁCIÓK KÖZÖTTI TÖRÉSVONAL A NYELVJÁRÁSI NYELVHASZNÁLATBAN - ESETTANULMÁNY

\author{
Generation Gap in Regional Dialect Use: a Case Study \\ Generacijski jaz u upotrebi dijalekata
}

A tanulmány a Szögedi Szociolingvisztikai Interjú kutatás egy kétgenerációs interjújának elemzése. A kettős interjú adatközlői anya (42 éves) és leánya (12 éves) voltak, akik Szegeden élnek. A két adatközlő nyelvhasználatának dialektológiai szempontból legfeltünőbb sajátossága, hogy az anya következetesen a szegedi $\ddot{o}$-ző nyelvváltozatot beszéli az interjú során, ezzel szemben lánya egyáltalán nem $\ddot{o}$-zik. Fiatalabb interjúalanyunk nyelvi viselkedését különösen érdekessé teszi az a tény, hogy a családban három generáció él együtt, és mind a nagyszülei, mind szülei $\ddot{o}$-ző nyelvjárásban beszélnek. A kétgenerációs interjú szövegét az alábbi szempontok alapján elemzem: a) hogyan vélekedik anya és leánya az ö-ző nyelvjárásról és a köznyelvről; b) hogyan vélekednek a másik nyelvhasználatáról; c) mit gondolnak arról, hogy a másik miért éppen úgy beszél, ahogy. Esettanulmányom a generációk közötti nyelvi diszkontinuitás bizonyos motívumaira vethet fényt a legkisebb beszélői közösség, a családban együtt élő beszélők szintjén.

Kulcsszavak: nyelvi attitűd, nyelvjárás, generációs eltérések, ö-zés

\section{Kutatási elözmények, korpusz}

A Szögedi Szociolingvisztikai Interjú (SZÖSZI) keretében készült az a kétgenerációs interjú, amely az elemzés alapjául szolgál. A két beszélgetés teljes átiratát közöltük korábban a SZÖSZI első eredményeit bemutató kötetben elemzés és kommentárok nélkül (Kontra-Németh-Sinkovics 2016, 200-271). Elemzésem korpusza ez a két publikált interjú. 


\section{Az interjúalanyok családjának nyelvi helyzete}

Az édesanya (K36) 42 éves, leánya (L11) 12 éves volt az adatfölvétel idején. A család Szeged külső részén, egy teljes egészében falusias lakónegyedben él, ahol a Szeged környéki nyelvjárás használatának jelentős múltja van. A korábban önálló települést jóval a XX. századot megelőzően csatolták Szegedhez. Három, korábban (míg a dédszülők is éltek) négy generáció élt együtt, a szülők, nagyszülők, dédszülők mind a Szeged környéki nyelvjárás született beszélői, akik otthon, egymás között az ö-ző Szeged környéki nyelvjárást használják, és ezen a nyelvváltozaton szólalnak meg más nyelvhasználati színtereken is. A családtagok, pontosabban a szülők és gyermekeik közötti nyelvhasználati különbségről ad pontos helyzetleírást az édesanya az interjúban:

Nagyon-nagyon érdekös, és soha nem gondoltam vóna, hogy így alakul, mert mindkét lányomat kizárólag ö-vē tanítottam beszélni (a családba is, méghozzá egy olyan családba élünk, ami többgenerációs, tehát együtt lakunk anyukámékkā, sőt régebben még az én nagyszüleim is ott laktak). Tehát az én lányaim abba születtek bele, hogy ott van a dédimama, ott van a nagymama, ott vannak anyuék, és mindönki ö-vē beszél. A másik nagyszülő is ö-vē beszél, aki tápéi [...] és mégis mekegnek a lányaim.

\section{A kutatás fö kérdései}

Kiss Jenő írja a mai magyar nyelvjárások fennmaradásáról a dialektológia tankönyvben: „A nyelvjárások jövője szempontjából meghatározó a nyelvjárási elsődleges nyelvváltozatú szülőknek, illetőleg a családnak az a döntése és gyakorlata, hogy nyelvjárási környezetben sem nyelvjárásban, hanem köznyelven szocializálják gyermekeiket” (Kiss 2001, 248). A továbbiakban azt fogom bemutatni, hogy - bár Kiss (2001) általánosítása helytálló - a vizsgált család nyelvhasználati szokásai azt is megmutatják, hogy az általa említett feltétel inkább szükséges, mint elégséges feltétele a nyelvjárás következő generációra való hagyományozódásának.

Az elemzés tárgya pedig az, hogyan lehetséges az, hogy édesanya és gyermeke gyökeresen eltérő módon használja anyanyelvét (az otthoni környezetben, családi közegben is) a nyelvjárás - standard kontinuum vonatkozásában. Megkísérelem föltárni azokat a tényezőket, amelyek magyarázhatják ezt a generációk közötti éles nyelvhasználati kontrasztot. A tanulmányban nem vállalhatom a korpusz teljes körü földolgozását a nyelvhasználat, a metanyelvi 
információk, nyelvi attitüdök és nyelvi ideológiák vonatkozásában. A vizsgálatban elsősorban a két adatközlő nyelvi attitüdjeinek föltárása a célom, mert úgy vélem, a családon belül kialakult helyzetet leginkább az attitüdtényezők magyarázhatják számunkra. Ezek elemzéséhez az alábbi kérdések vihetnek közelebb bennünket.

A) Mi lehet az oka annak, hogy a „prototipikus” Szeged környéki nyelvjárást beszélő családban nevelkedő gyermek beszédében nyomait sem találjuk a Szeged környéki nyelvjárás jellemzőinek, így az ö-zésnek sem?

B) Hogyan éli meg az otthoni ellentmondásos nyelvhasználati helyzetet a két interjúalany: az édesanya és leánya?

Ahhoz, hogy a fönti kérdésekre megkíséreljünk érvényes választ adni, szükséges tisztázni az alábbiakat.

a) Mit tart L11 és K36 a saját beszédéről?

b) Mit tart L11 és K36 a másik beszédéröl?

c) Milyen narratívájuk van a saját beszédükkel kapcsolatban: miért éppen úgy beszélnek, ahogy?

d) Milyen narratívájuk van a másik beszédével kapcsolatban?

e) Mennyire vannak tudatában, hogy a másik hogyan értékeli beszédüket?

f) Indukál-e a másik értékelése valamiféle nyelvhasználati változást beszédükben?

\section{Az interjú szereplöinek profilja}

Ebben a részben a két interjúalany profilját vázolom fel az interjú szövegének elemzése alapján, hogy azután a profilok ismeretében kíséreljek meg választ adni a föltett kérdésekre. A szempontok, melyek alapján jellemzem a szereplőket: a nyelvelsajátítást meghatározó családi környezet, a köznyelvhez, a szegedi nyelvjárási beszédhez, továbbá az $\ddot{o}$-zéshez, az $\ddot{o}$-ző beszédhez (és beszélőkhöz) való viszonyulás, a szegedi identitás megléte, erőssége és végezetül viselkedésük olyan helyzetekben, amelyek nyelvhasználatinormakonfliktust mutatnak.

\section{K36 profilja}

Az édesanya, K36 született szegedi $\ddot{o}$-ző beszélö, akinek szülei, nagyszülei is a Szeged környéki nyelvjárást beszélték anyanyelvváltozatukként. Szegeden 
született, és egész életében a város egyik falusias, külső negyedében élt. Szülei szintén a Szeged környéki nyelvjárás született beszélői. K36 édesanyja földmüves családban született, ahol „ö-ve beszétek mindig”. Alap-, közép- és felsőfokú tanulmányait Szegeden végezte. Az adatközlő férje szintén a nyelvjárás született beszélője.

K36 erős szegedi identitással rendelkezik, aki szükebb lakóhelyének kultúráját, nyelvhasználatát figyelemmel kíséri. Hagyományápoló megfontolásból még nyelvjárási beszélgetéseket is rögzített szükebb lakóhelyén, melyekböl szövegközlések születtek.

Rendkívül tudatos, nyelvi önreflexióra képes beszélő, akinek releváns megfigyelései vannak saját beszédéről, annak változásáról az egyes szituációkban és életkorokban. Az erős szegedi identitás nála összeforr a Szeged környéki nyelvjárás tudatos és minden nyelvhasználati színtérre kiterjedő használatával. Öntudatos, büszke $\ddot{o}$-ző beszélő, aki a szegedi beszédet szépnek tartja, ezzel szemben a kevésbé labializáló nyelvváltozatokat (Egerben hallott beszélt nyelv, köznyelv) gyakran címkézi ,,mekegés”-nek. Az ö-ző beszédhez való hozzáállását jól mutatja az alábbi idézet: ,amikó én most úgy érzöm, hogy öö énneköm ö-vē kő beszénöm, mer ez valahogy belölrő jön, akkó én mindig ö-vē beszélök." Azzal is tisztában van, hogy nyelvhasználata már Szegeden is föltünő lehet, de a pozitív reakciókat emeli ki: „Má Szegedön is előfordút igen, hogy fötünést keltöttem, me éppen nem beszét úgy senki, de úgy pozitív értelömbe.” A terepmunkás provokatív kérdésére elárulja azt is, melyik magyar nyelvváltozatot tartja a legszebbnek - egyszersmind azt is, hogy a nyelvjárás kulcsjelenségének az ö-zést tartja.

tm: és szerinted melyik vidékön beszélnek a legszöbben magyarul?

K36: mm Énneköm tetszik az ö-zés, tehát most erre mondhatom azt is, hogy akár Szegedön.

Az első eset, amikor ráébredt, hogy kortársai az ország más részein másként használják anyanyelvüket, Parádsasváron történt. Egy nyári táborozás alkalmával, hetedik osztályosként jutott erre a felismerésre. Így emlékszik erre: „És ott vöttem észre először azt, hogy ëngöm ezé kinevetnek. [...] Mondjuk ez ëgy kéthetes közjáték vót, tehát egy olyan mé mély nyomot nem hagyott bennem. Mē addig tartott ugye a tábor, hazagyüttem, oszt folytattam tovább az ö-zést."

Nyelvi-nyelvjárási attitüdjét mutatja, hogy akkor is vállalta az ö-zést, amikor teljesen eltérő nyelvjárási környezetben kitünt az ö-zésével, és ebböl konfliktusa is származ(hat)ott. Felnőttként Egerbe került egy évre, rendkívül eltérö módon beszélő palócos, $e$-ző környezetbe, ám ekkor sem igyekezett kerülni a 
feltünő szegedi nyelvjárási jegyeket. Így summázta ezt az időszakot: „Inkább csak mosolyogtak, amikor $\ddot{o}$-ve beszétem."

A teljes képhez hozzátartozik az is, hogy volt egy olyan időszaka is életének, amikor nehéz volt vállalnia a családjukban használt nyelvváltozatot, és megkísérelt alkalmazkodni az iskola nyelvhasználati közegéhez:

amikó a városba kerültem iskolába, akkó dere- kezdött e derengeni, hoppá ez [ti. az ö-ző beszéd] talán ciki ëgyesök szömibe. Igen. [...] próbáltam igazodni, igen. Tehát öö próbáltam bizonyos közegökbe abszolút nem öö észrevötetni azt, hogy én ö-vē beszélök. Tehát az életömnek későbbi szakaszába jött az elő, hogy abszolút nem érdeköl, ki mit gondol.

\section{L11 profilja}

L11, ahogy föntebb láthattuk, olyan többgenerációs családban sajátította el anyanyelvét, amelynek tagjai mindannyian a Szeged környéki nyelvjárás született beszélöi, és egymás közötti kommunikációjukban ezt a nyelvváltozatot használják.

Arra a kérdésre, mennyire tartja magát szegedinek, azt mondja, hogy „közepesen". Amikor bővebben beszél erről, akkor viszont nagyon érdekes adatot szolgáltat a saját nyelvi ideológiájáról, arról, hogyan viszonyul ahhoz, hogy az emberek különféleképpen használják az anyanyelvüket. (A nyelvi ideológia kifejezést abban az értelemben használom, ahogyan Lanstyák [2011, 15-16] határozza meg a fogalmat.) Az a nyelvi ideológia, amely megjelenik válaszában, minden bizonnyal nem független a családi/szülöi hatásoktól. Válaszaiból kiderül, hogy ő azt az embert tartja ,,igazi” szegedinek, aki a Szeged környéki nyelvjárást beszéli, tehát a szegedi identitást szorosan hozzákapcsolja a szegedi nyelvjárási beszédhez. Mivel ő nem így beszél, ezért tehát nem vallja magát „vérbeli szegedi"-nek a terepmunkás kérdésére válaszolva. Az interjú más részleteiből az is kiviláglik, hogy képes lenne a helyi nyelvjárás bizonyos jegyeit használni.

tm: Ühüm. Értö, értöm öö. Jó. Akkor most azt kérdözném, lönne ëgy ilyen válaszlapunk [zörög a papírral], amin az a kérdés, hogy mennyire tartod magad szegedinek. Ugyë mondtad, hogy egész életödben itt éltetök, és akkó ëgyet be kéne karikázni, amit úgy érzöl, hogy rád nagyon érvényös. L11: Hát olyan mm közepesen szerintem.

tm: Közepesen?

L11: Nem vagyok olyan vérbeli szegedi, hogy (mármint hogy) nem is úgy beszélek. Hát mm e-vel beszélek, nem ö-vē például az is. Meg hát nem tudom. 
tm: Ühüm. Akkor mondasz neköm egy mondatot, amit mondjuk az anyukád úgy mondana?

L11: Emöntem a bótba, vöttem kenyerö-kenyeret mög sajtot.

L11 pozitív véleménnyel van mások ö-ző beszédéről, annak ellenére, hogy ö maga - saját bevallása szerint - nem használja, erre a beszélgetésben kétszer is utal: „(nekem) nem zavar. Igazából mm jó hallani ezt.” Az interjú egy másik pontján pedig így:

tm: És zavar-ë az, hogy valaki ö betűvel beszél?

L11: Nem, engem nem idegesít. mm Igazából jó hallani.

Ez a pozitív viszonyulás ellentmondani látszik saját nyelvhasználatának, de erről az elemző részben szólok részletesen.

\section{Mi történik?}

Érdemes közelebbről megvizsgálnunk, hogyan, milyen kifejezésekkel írja le K36 a családban kialakult nyelvhasználati helyzetet, L11 (és kishúga) nyelvhasználatát.

a) „és mégis mekegnek a lányaim.”

b) „de ök nem ö-znek.”

c) „és most mán kizárólag mekegve beszének.”

d) „tudja, hogy anyja-apja $\ddot{o}$-vē beszél, de ő $e$-vē válaszol.”

A fönti megnyilatkozásokban kétszer semleges kifejezést használ az ö-zés kerülésének megnevezésére (nem ö-znek, e-vē válaszol), ugyanakkor szintén kétszer egy pejoratív, értékminősítést is magában foglaló szót (mekegnek, mekegve beszének). Ezek a nyelvjárásban eredetileg gúnyos értékü kifejezések, melyek gyakori használatúnak számítanak. Bálint (1957, II. 142) így ír a szóról: „,mekeg 3. 'urasan, nem ö-zve beszél paraszt létére”. A szót a SZÖSZI adatközlőinek egyik típusának jelölésére mi magunk is használtuk (elsőként Berente-Kontra-Sinkovics 2016). Az, hogy K36 ezeket használja, két dolgot jelezhet számunkra: egyfelől azt, hogy az e-ző beszélők megnevezésében is követi a Szeged környéki nyelvjárást, másfelől nyilvánvalóan azt is, hogy érzelmileg nem tudja függetleníteni magát lánya, L11 e-ző beszédétől, és ebben az esetben inkább negatív érzelmi reakcióra utal. K36 ezzel kapcsolatos érzelmeire a későbbiekben még kitérünk. 
L11 leírása az otthoni helyzetről meglehetősen tárgyszerü, érzelemmentes. L11 tudatosan reflektál az otthoni/családi kommunikáció kettősségére: arra, hogy a szülők és a gyermekek más nyelvváltozatot használnak. Emellett pontos megfigyeléssel szolgál azzal kapcsolatban, hogy a szülők és gyermekek beszédében is tapasztalható az ë/ö változót érintő ingadozás.

L11: hát anyáék $\ddot{o}$-vel beszélnek, mi meg $e$-vel, és akkor hát ilyen keverés van a beszédbe.

L11: Meg valamit ők is $e$-vel mondanak, valamit meg mi $\ddot{o}$-vel mondunk. [...] de lehet, hogy ez csak ilyen egyszeri alkalom.

\section{Hogyan értékelik azt, ami történik?}

K36 öszintén vall arról, váratlanul érte és érzelmileg negatívan érinti az, hogy gyermekei $e$-zve beszélnek és kerülik az $\ddot{o}$-zést: „Hát rossz érzés. Rossz érzés, me soha nem gondoltam volna. Nem vállalják vagy..." Egy másik megnyilatkozásban pedig így: „Hát igen ez ez úgy rossz érzés.” Az interjúban többször használja a rossz érzés kifejezést ezzel kapcsolatban. Nem mondja ki ezeket a szavakat, de talán a csalódás és a kudarc szó fejezi ki legtalálóbban azt, amit érez. A be nem fejezett, Nem vállalják kezdetủ mondat állítmánya arra utal, hogy ő maga is tudatos döntésnek tartja, hogy gyermekei kerülik az ö-zést. Abban, hogy ez tudatos döntés következménye L11 esetében, valószínúleg nem is téved.

K36 attitüdje ugyanakkor nem teljesen beletörődő. A terepmunkás, de inkább saját maga számára fönntartja és felvillantja annak a lehetőségét, hogy L11 (és testvére) nyelvhasználata a jövőben megváltozhat. Megfogalmazza az ezzel kapcsolatos reményét is egyik válaszában: „lehet, hogy előbb-utóbb majd rádöbben erre, hogy ez nem ciki, és visszatér majd az ö-zésre".

L11 máshogyan viszonyul édesanyja beszédéhez, mint az édesanyja az övéheza viszony aszimmetrikus. Nem állítja, hogy zavarná édesanyja $\ddot{o}$-zö beszéde, ezzel kapcsolatos érzelmeiről nem szól. Viszont pontosan érzékeli, hogy édesanyját (édesapját is) zavarja az ő e-ző beszéde. Az ezzel kapcsolatban használt szó érzelmileg semmiképpen sem közömbös állapotra utal: idegesíti őket ez a fajta beszéd. Később, amikor a terepmunkás visszakérdez a szóra, önkorrekcióval finomítja ezt az érzelmileg telített és egyértelműen negatív kifejezést, fölváltva azt egy semlegesebbel. Hogy melyik minősítés felel meg jobban saját tapasztalatainak? Ezt biztosan nem tudhatjuk, de az önjavítás előtti minősítést nagyobb valószínűséggel tarthatjuk hitelesnek, hiszen a korrekció már inkább azt szolgálhatja, hogy „kifelé” (a terepmunkásnak) kevésbé konfliktusos képet mutasson a családi nyelvi helyzetről. 
L11: Csak anyáékat idegesíti, hogy e-vē beszélek. tm: Idegesíti őket?

L11: [...] fura nekik, hogy én így beszélek, ők meg ö-vel beszélnek. tm: és szoktak erre valamit mondani $[\ldots]$ ?

L11: Hát hogy otthon vagyunk, hogy beszéljek ö-vel, de de tudok úgy beszélni, csak nem akarok. mm Nem tudom.

A fönti párbeszéd részlet még egy érdekes információt tartalmaz a szülő és gyermeke közötti normakonfliktussal kapcsolatban: ez pedig az, hogy K36 buzdítja az $\ddot{o}$-ző beszédre lányát. Ahogyan az anya ezt megfogalmazza, abból megállapítható: tisztában van azzal, hogy L11 az iskolában (és más nyilvános színtereken) a környezet föltételezett reakciói miatt nem használja az ö-zést. Az otthoni környezetet pedig éppen az különbözteti meg az iskolai színtértől, a családban nem kell negatív reakciókra számítania az ö-zve beszélő gyermeknek.

\section{Miért történik?}

K36-ot érezhetően mélyen foglalkoztatja a probléma, hogy miért hagyták el gyermekei anyanyelvjárásukat. Ezt az is mutatja, hogy kidolgozott narratívája/magyarázata van a történésekre, mely implicit módon az okokat is magába foglalja. Narratívája arra épül, hogy a nyelvelsajátítás korai szakaszában a gyermekek még ugyanúgy beszéltek, ahogyan ő, csak később, a családon kívüli környezeti tényezők miatt elhagyták ezt a nyelvváltozatot. Meg kell jegyeznünk, hogy helyzetértékelése az iskolatársak szerepével kapcsolatban minden bizonnyal pontosnak tekinthetö.

„Talán mikó mögtanútak beszéni, akkó mönt az ö-zés egy-két évig, és ahogy bekerültek a bölcsibe, oviba, egybő, és most mán kizárólag mekegve beszének."

„[...] a nagy mög azt mondja, hogy me nem beszének mán így az iskolába, és hát az ciki."

„[...] és én ezt annak tudom be, hogy az ő korosztályukba má nem úgy van, mint az enyémbe vót, hogy öö nálunk az egész osztály ö-zött, és azé nem vót ciki ö-vē beszéni, őnáluk má nem ö-znek a gyerökök, me e-vē tanították őket beszéni."

Ezt a narratívát így összegzi a végén: „És nagy-nagyobb hatássa vót rá ezáltal az óvoda mög az iskola, mint a saját családja." Ezt a tényt nehezére esik elfogadnia, annak ellenére, hogy a dialógus egy korábbi részében maga 
mesél róla, hogy már az ő diákkorában sem volt „idilli” a helyzet az iskolában a nyelvjárási nyelvhasználat szempontjából, és neki is voltak olyan osztály-

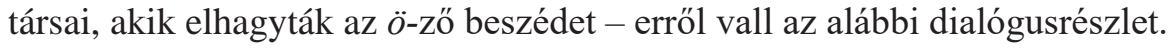

tm: És amikor általános iskolás voltál, akkor ugyanúgy beszéltél, mint a többi gyerök?

K36: Ugyanúgy, me a többiek is ö-ztek. Úgy hetedik-nyolcadikba, mikó mán kezdtek öö kezdtünk kamaszodni, és akkó a többiek talán kicsit korábban értek, mint én, korábban kezdtek diszkóba járni, má úgy hetediknyolcadikba, és akkó kezdtek rádöbbenni, hogy talán ëgy kicsit parasztos az ö-zés, és ezé e- ëgyesök ekezdtek mekegni. De egymás közt mindig csak ö-vē beszéltünk. öö Hát az órákon viszont e-vē felētünk Tehát a tanárokkal e-vē, mekegve beszétünk csak.

K36 felvillant egy másik lehetséges magyarázatot is gyermekei standard(dá vált) nyelvhasználatával kapcsolatban, de ezt mint elvetett lehetőséget mondja el. A magyarázat arra épül, hogy a nyelvelsajátítás során az este olvasott mesék nyelvezetének köszönhetően nagy volt a gyermekek köznyelvi hatásnak való kitettsége - ebben az az ironikus, hogy a meséket ő maga olvasta esténként. Az e-ző irodalmi nyelv hatásáról így vallott:

Kezdetben arra is gondótam, hogy amikó meséket, mer rengeteget olvastam, föleg a nagyobbnak, és ugye a mesék azok azok e-vē vannak írva, e-vē olvastam fö, hogy nem-ë ezé? De aztán utána amikó ēkezdött járni bölcsibe, oviba, úgy fokozatosan át-áttért az e-zésre, biztos tudja ő, hogy hogy kéne ö-vē mondani.

Azonban mint az idézett szövegrész vége mutatja, ezt a magyarázatot ő sem tartja valószínünek.

Az idézet zárórészéből fontos kiemelnünk azt az információt, hogy K36 úgy véli, a lánya képes az ö-zésre - ez egybevág azzal, ahogyan L11 maga is megítéli saját nyelvjárási kompetenciáját, és azzal, hogy felszólításra képes volt egy olyan mondatot alkotni, melyben $\ddot{o}$-zte a szavakat (lásd az L11 profilja részben). Az interjúban is tapasztalható egyszeri (!), minimális „kilengése az ö-zés irányába: „Szoktunk mönni (!) iskolába, bár annyira nem tudok jégkorizni, de próbálok."

Amikor L11 beszél arról, miért úgy használja anyanyelvét, ahogyan, akkor lényegileg megismétli édesanyja első narratíváját az óvoda és iskola szerepével kapcsolatban - talán ezt is készen kapta édesanyjától, mint a már említett nyelvi ideológiát: „Mer hát ugye a bölcsibe mindenki e-vel beszélt meg az oviba is. 
És akkor úgy tanultam meg beszélni." De van egy sokkal fontosabb megnyilatkozása is, amikor arról szól, miért nem beszélnek a diákok nyelvjárásban az iskolában. Ezen a ponton kimondja: azért nem $\ddot{o}$-zik egyetlen osztálytársa sem (és nyilván ő maga ugyanígy), mert félnek a kortársi közösségen belüli nyelvi alapú megbélyegzéstől. Hogy az ilyen, a nyelvjárás kortárs csoporton belüli használatát gátló iskolai légkör ellen lehet-e valamit tenni, arról a későbbiekben ejtek szót.

tm: És nincs olyan osztálytársad, aki mondjuk $\ddot{o}$ betüvel beszél?

L11: nincs, mer hát ez ki is kö-közösítenék, hogy hogy hogy hogy máshogy beszél, mint a többi, hogy másmilyen.

tm: Aha. Tehát akkor úgy gondolod, hogy a-az, aki így beszélne, az mög lönne szóva?

L11: Hát igen.

K36 kisebbik gyermekének e-zésével kapcsolatban kiemelendőnek tart még egy motívumot, amely a fiatalabbik lány nyelvi viselkedését befolyásolhatja: ez pedig a nagyobbik testvér által képviselt nyelvimagatartás-minta: „hát a kicsi az inkább azé, mē majmolja a nagyot, mē a nagy is ö-vē besz-e-vē beszél."

\section{Hogyan beszél egymással anya és leánya?}

Az iskolai nyelvhasználati színtér után érdemes azt is megfigyelnünk, mit mond K36 és L11 arról, hogyan és miért éppen úgy beszélnek otthon egymással, valamint arról, mi a véleményük a másik otthoni beszédéröl.

K36 az interjúban egyértelművé teszi, hogy nem hajlandó változtatni beszédén, akkor sem, ha e-ző lányával (lányaival) kommunikál: „De én nem beszélök már velük akkó së, tehát én nem váltok át, amikor hozzájuk szólok mekegésre, e-zésre, de ők nem ö-znek." Az általa elmondottakból az is kiderül, rossz megoldásnak tartja, hogy más (föltételezhetően eredetileg született ö-ző szülők) azért e-zve beszélnek gyermekükkel, mert „meg akarják tanítani” az e-ző beszédre: „Tehát azér én nem váltok át e-re, mint sok szülő, hogy me a gyerekemet e-vē tanítsam beszéni, mer nem." Sajnos ezen a ponton nem indokolja részletesen magatartását, de az interjú egészéből kikövetkeztethető, hogy azért teszi ezt, mert szeretné, ha gyermeke is úgy beszélné anyanyelvét, ahogyan ő maga, az ő szülei, nagyszülei. Stratégiája ugyan eddig nem járt sikerrel, de vélhetően továbbra is ragaszkodik hozzá.

L11 következetesen $e$-zve szól $\ddot{o}$-ző édesanyjához, és a nem is titkolt szülöi szándék ellenére sem hajlandó ö-zésre váltani. A dialógusban egy helyen nagyon 
sokat hezitál, amikor arról kell beszélnie, milyen érzés az édesanyjának, hogy ö, a gyermeke nem $\ddot{o}$-zve beszél hozzá. L11 kijelenti azt is, hogy ő így elégedett a saját beszédével.

Az L11 által mondottakból érzékelhető, hogy ellentmondásos az ö-zéssel kapcsolatos viselkedése: ő maga tudatosan nem beszél így még édesanyjával sem, pedig képes lenne rá. Ezzel ellentétben, amikor mások ö-zéséröl van szó, akkor - ahogyan már föntebb, profilja megalkotásánál bemutattam - pozitív attitüdöt mutat. Az ő nyelvjáráshoz és $\ddot{o}$-zéshez való aktív viszonyulása és attitüdje párhuzamba állítható a SZÖSZI kutatás 13-15 éves korosztályában tapasztaltakkal: az ő korcsoportjukban nincsen nyílt presztízse az ö-zésnek, sőt többen beszámolnak megbélyegzésről az iskolában, ugyanakkor az otthoni-családi környezetben jó néhányuknál van/lehet rejtett presztízse (KontraNémeth-Sinkovics 2016, 124-125).

\section{Megfigyeléseink összegzése}

A kettős interjúból megállapítható, hogy L11 képes az ö-ző szegedi beszédre, de nem így beszél. Ö maga ugyanezeket állítja saját beszédét jellemezve, és az interjú során mutatott nyelvhasználata is ezt erősíti meg. Az otthoni környezetben, szüleivel, nagyszüleivel kommunikálva sem $\ddot{o}$-zik, és a nyelvjárás más, kevésbé emblematikus sajátságai sem fordulnak elö beszédében, annak ellenére sem, hogy szülei, nagyszülei $\ddot{o}$-ző Szeged környéki nyelvjárást használnak. L11 esetében tehát elmondhatjuk: a támogató otthoni nyelvjárási környezet nem meghatározó motívuma beszédszokásainak, kódválasztásának. Az, hogy így beszél, valószínüleg inkább tudatos döntés következménye - ezt a feltételezést erősíti, hogy az anyai buzdítás ellenére sem $\ddot{o}$-zik otthon. L11 döntése azonban nem jelent teljesen szabad választást: választása szabadságát meghatározó módon korlátozza az iskolai kortárs közösség, melyben L11 mindennapjait tölti. Ebben a közegben az $\ddot{o}$-zésnek nincsen nyílt presztízse, és ami ennél súlyosabb: használata az adatközlő véleménye szerint kiközösítéssel is járna. Az eddigiek fényében ellentmondásként hathat, de az interjú alapján kijelenthető: L11 viszonyulása mégis alapvetően pozitív az ö-ző Szeged környéki nyelvjáráshoz, mások $\ddot{o}$-ző beszédéhez, és így a családtagjai által otthon használt nyelvváltozathoz is (,jó hallani”).

L11 édesanyja és maga L11 is (vélhetően az édesanyjától hallott narratívát visszhangozva) a bölcsődei és óvodai évektől számítják a nyelvjárás kerülését, és az ottani környezetet tartják kiváltó oknak. A nyelvelsajátításnak a bölcsődeióvodai időszakot megelőző szakaszáról azt állítják, hogy L11 az otthoni $\ddot{o}$-ző 
nyelvjárást beszélte. Mindketten úgy tartják, hogy L11 azért nem követi szülei beszédét, mert az iskolában más nem beszél így, és emiatt megbélyegzés érné. K36, az édesanya nem helyesli, és talán kudarcnak tartja, hogy L11 e-ző, nem ö-ző nyelvjárási változatot beszél. Az anya legalább az otthoni környezetben „elvárná” az ö-zést, erről leginkább az árulkodik, hogy biztatja gyermekét az ö-zésre. L11 tisztában van azzal, hogy e-ző nyelvhasználata milyen hatással van édesanyjára, és hogy milyen anyai reakciókat vált ki az ő beszéde. Maga L11 elfogadó módon viszonyul szülei, nagyszülei (és mások) nyelvjárási beszédéhez, nem várja el tőlük, hogy változtassanak rajta, azonban a föntebb említett okok miatt nem akar változtatni beszédén.

Megfigyeléseinket általánosítva megállapíthatjuk, hogy a gyermek nyelvhasználata egy a nyelvjárási beszédet tökéletesen támogató, „ideális” családi környezetben is a standard felé tolódhat el. A nyelvjárási(as) beszéd kerülésének legfőbb kiváltó oka az, hogy az érintett korosztály esetében már lényegesen fontosabb a kortárs csoport hatása, mint az otthoni/családi környezeté. Ugyanerről a jelenségről így ír Kiss $(2001,249)$ a dialektológia-tankönyv már idézett fejezetében: „A legújabb korban csökken a családnak s növekszik a tágabb környezetnek (iskola, kortárscsoportok, tömegtájékoztatási eszközök) a szerepe az anyanyelv átadásában, az anyanyelv elsajátításának az irányításában."

\section{Következtetések}

Fölmerül a kérdés, tehetünk-e valamit az esettanulmányban leírt jelenség ellenében és a nyelvjárások fönnmaradása érdekében a fiatal generációk nyelvjáráshoz füződő attitüdjeinek formálásával? Általánosságban megfogalmazva talán lehetne azért tenni az iskolai anyanyelvi nevelésben, hogy az iskola közegében ne legyen kirívó jelenség a nyelvjárási beszéd, és hogy a kortárs csoport hatása ne oltsa ki az otthoni környezet nyelvjárást megtartó eröit.

Szükséges lenne, hogy az iskolában tanító pedagógusok támogassák a nyelvjárási megszólalásokat annak érdekében, hogy az L11-hez hasonló, nyelvjárását beszélni képes gyermekek merjenek anyanyelvváltozatukon megszólalni. Egy ilyen támogató környezet kialakításában kulcsszereplők a pedagógusok, akik saját személyes példamutatásukkal közvetve is formálják diákjaik attitüdjeit, és akarva-akaratlanul nyelvi ideológiáikat is továbbadják tanítványaiknak. Másfelől az is fontos lenne, hogy közvetlen hatást is kifejtsenek: vitassák meg ezeket a kérdéseket az anyanyelvi órákon. Hogy ezeket a lehetőségeket az oktatásban ki tudjuk használni, szükség van arra is, hogy a magyar nyelv és irodalom szakos tanárképzésben megtaláljuk a helyét a kérdéskör megvitatásának - például dialektológiai, szociolingvisztikai és tanításmódszertani tematikájú órákon. 


\section{Utószó}

Nagyon valószínü, hogy más, nem szegedi iskolai környezetben ettől eltérö hatása is lehet a kortárs csoportnak. Föltételezhetö, hogy - a Szeged környéki nyelvjárás nyelvföldrajzi hatókörében maradva - Makón vagy Hódmezővásárhelyen, ahol az iskolákban is hétköznapi jelenség az ö-zés, és ahol az egész településen pozitívabb az ö-zés megítélése, sokkal kevésbé kényszerülnek a diákok anyanyelvjárásuk elhagyására.

A kettős interjú ugyanakkor arra is adatot szolgáltatott, hogy a generációk közötti kontinuitás vagy annak hiánya bizonyos családokban szinte kiszámíthatatlan mintázatokat hoz létre. Az alábbi idézetben leírt helyzet egészen különös, értelmezéséhez pedig célirányos interjúkra, lényegesen több adatra lenne szükség:

A párom testvérének van öt gyereke, és az öt gyerekből négy ö-vē beszél, egy valamiér mekegve. Nem tudom. És ővele a szülők is e-vē beszélnek. Tehát az, hogy mitő más az a gyerek, vagy mér alakult ez így ki, mondjuk megnősűt már az a fiú éppen, öö és pont olyan helyre is kerüt, ami nagyon elit. Mintha érezte vóna az anyukája előre, hogy e fog kerülni az ország túlsó felébe és ezé őt nem kell ö-vē megtanítani beszélni.

\section{Irodalom}

Bálint Sándor. 1957. Szegedi szótár I-II. Budapest: Akadémiai Kiadó.

Berente Anikó-Kontra Miklós-Sinkovics Balázs. 2016. Egy szegedi ö-ző, e-ző és mekegő beszélő nyelvhasználatának és nyelvi attitüdjeinek összefüggései. In Sztenderd Nem sztenderd: variációk egy nyelv változataira, szerk. Kozmács István-Vančo Ildikó. 97-107. Lakitelek: Antológia Kiadó.

Kiss Jenő szerk. 2001. Magyar dialektológia. Budapest: Osiris Kiadó.

Kontra Miklós-Németh Miklós-Sinkovics Balázs. 2016. Szeged nyelve a 21. század elején. Budapest: Gondolat Kiadó.

Lanstyák István. 2011. A nyelvi ideológiák néhány általános kérdéséről. In Nova Posoniensia. 13-57. Pozsony: Szenczi Molnár Albert Egyesület-Kalligram Kiadó. 


\section{GENERATION GAP IN REGIONAL DIALECT USE: A CASE STUDY}

This presentation discusses a two-generation interview carried out within the Szeged Sociolinguistics Research project, whose text was included in the Kontra et al. (2016) volume, but was not analyzed there. The interviewees are a 42-year-old woman and her 12-year-old daughter, who live in the same household in Szeged. The most striking characteristic of their language use from the dialectological point of view is that the mother consistently uses the Szeged dialect throughout the interview while her daughter does not use it at all. The daughter's language use is especially interesting if we consider the fact that both her grandparents and parents use the dialect in their three-generational household, including their communications with her. I analyze the following aspects of the two-generation interview: (i) what mother and daughter think regarding the regional dialect vs. the standard, (ii) what they think regarding the other one's language use, and (iii) what they think the reasons are for the other one's language use. This case study may shed light on certain aspects of the workings of intergenerational discontinuity of language use at the level of the smallest speech community, the family.

Keywords: regional dialect, standard, generational differences, Szeged dialect

\section{GENERACIJSKI JAZ U UPOTREBI DIJALEKATA}

Rad predstavlja analizu ispitanica koje pripadaju dvema generacijama u okviru istraživanja pod nazivom „Sociolingvistički intervju Segedina“. Ispitanice su majka (42 godine) i ćerka (12 godina), stanovnice Segedina. Razlika u upotrebi jezika ove dve ispitanice iz perspektive upotrebe dijalekta se ogleda najviše u tome što majka dosledno upotrebljava segedinsku varijantu sa samoglasnikom ö, dok ćerka uopšte ne upotrebljava ovu dijalekatsku pojavu. Jezičko ponašanje mlađe ispitanice čini interesantnim podatak da u porodici žive tri generacije te da njeni baba i deda kao i roditelji govore narečje sa samoglasnikom ö. Tekst dvogeneracijskog intervjua se u radu analizira prema sledećim kriterijumima: a) kakav stav imaju majka i ćerka prema narečju i prema standardnom govornom jeziku; b) kakvo mišljenje imaju o govoru one druge; c) šta misle o razlozima zbog kojih ona druga govori baš tako. Studija želi da ukaže na neke motive diskontinuiteta u jezičkom ponašanju različitih generacija, s posebnim osvrtom na najmanju govornu zajednicu, porodicu.

Ključne reči: stav prema jeziku, dijalekat, narečje, generacijski jaz, upotreba samoglasnika 